\title{
A magyar iskola a CIA jelentéseiben
}

\author{
SOMOGYVÁRI LAJOS \\ Pannon Egyetem Modern Filológiai és Társadalomtudományi Kar \\ Tanárképző Központ
}

\begin{abstract}
Írásom az ötvenes évek hazai (és külföldi) historiográfiájában kevéssé felhasznált szempontot és megközelítést mutat be: a titkosítás alól feloldott CIA jelentések alapján a magyar iskoláról kirajzolódó képet vázolom fel. Az amerikai hírszerzés Magyarországhoz fúződő viszonyának áttekintése után ismertetem a forrásokat, bemutatva jellemzőiket és a dokumentumokból létrehozható csoportokat. Az elemzésben az iskolarendszert és az egyes iskolatípusokat bemutató szövegeket elemzem, különös hangsúllyal a szakképzésre, a nevelés-oktatás során felmerülő problémákra és 1956 hatásaira.
\end{abstract}

Kulcsszavak: CIA, hírszerzés, 1956-os forradalom, szakképzés.

\section{BEVEZETÉs}

Az amerikai külpolitika viszonya ismert Magyarországhoz a hidegháború kontextusában, amelyet a feltartóztatás, visszaszorítás, felszabadítás propagandaszólamai mellett a gyakorlati tétlenség jellemzett (Borhi, 1999). Charles Gati óta tudjuk (2006), hogy az amerikai hírszerzésben igen alacsony prioritást élvezett ebben az évtizedben Magyarország, ezért különösen fontos az a néhány fennmaradt jelentés, ami a magyar iskolarendszerrel kapcsolatos, hiszen megmutatja, hogy mit tartott fontosnak a CIA a téma kapcsán. Persze jó néhány torzító hatással kell számolnunk: a nyilvánosságra hozott dokumentumok mellett nem tudjuk, hogy maradtak-e titkosított jelentések, kérdés, hogy milyen információkhoz juthattak egyáltalán a hírszerzők, de ez még mindig jóval több, mint, amit a szovjet oldalról tudhatunk.

A CIA megalakulása után, 1948-ban mindössze tíz ember alkotta a James McCargar vezette, hét országot (Görögország, Törökország, Albánia, Magyarország, Románia, Bulgária és Jugoszlávia) ellenőrző főhadiszállást (Weiner, 2007. 34. o.), a növekvő feladatok ellátását tekintve a helyzet később sem javult. Az 1956-os forradalom teljesen felkészületlenül érte az amerikai hírszerzést, mindössze egy magyarul tudó ügynök tartózkodott 1950 óta a térségben (CIA Historical Staff, 1972; Katona Géza nevét Charles Gati fedte fel már idézett könyvében), ami nyilvánvalóan nem volt elég a kialakult helyzet kezelésére. Ezt 
követően vált fontossá a térség és benne Magyarország, a prognózisok felállításához több információra volt szükség, hogy előre megjósolhatóvá váljanak a bekövetkező változások. Ahogyan egy belső tájékoztató füzetben olvasható: "A magyar emberek kommunistaellenes felkelése 1956 októberében megmutatta annak fontosságát, hogy megértsük a magyarokat, a szovjet megszállókkal szembeni erőszakos szembenállásukat, illetve ennek jelentőségét a kommunista blokkon belül." Ennek érdekében országjelentés készítését és egy 10 hetes kurzust is terveztek a CIA központban, 1958 elejére, Magyarország gazdasági, politikai és társadalmi intézményeiről, a csatlóssá válás folyamatáról. ${ }^{1}$ A magyar kurzust végül szokatlanul magas létszámban, 30-an hallgatták meg a CIA központjában, ami indokolttá tette újabb tanfolyam indítását ${ }^{2}$ - a nagy érdeklődés valószínúleg az 1956-os forradalom utóhatásának és a magyar menekülteknek is köszönhető volt, mindenesetre egy új korszak kezdetét jelezhette a Magyarországgal kapcsolatos amerikai hírszerzésben.

A vázlatos áttekintés természetesen további finomításokra szorul, de 1956 korszakhatár jellege vitán felül áll, amit jelez, hogy a forradalom amerikaihírszerzési recepcióját is tartalmazó könyv már megjelent (Békés, Byrne és Rainer, 2002), de átfogóbb, nem a politikai eseményekre koncentráló kontextusban nem rendelkezünk hasonló munkával. Oktatás és hírszerzés kapcsolata is a szabadságharc leverése után artikulálódott hangsúlyosabban, a nyugatra emigráló és potenciális információforrásként szolgáló diákok, hallgatók CIA által történő beszervezése, kihallgatása révén (Sheridan, 2016). Ellenkező irányú, tehát amerikai diákok ügynökökként való felhasználásáról szóló múveket szintén publikáltak már Amerikában (egészen a hatvanas évektől, a legújabbak: Prados, 2006; Zwerling, 2011; Paget, 2015), csakúgy, mint a Világifjúsági Találkozókat hírszerzési terepként interpretáló monográfiát, ami Moszkva titkos befolyását is feltárta a nemzetközi diákszervezetekben (Kotek, 1996, 2005). Jellemző téma még a Szovjetunióval kapcsolatos amerikai információk, forgatókönyvek közzététele, főleg az atom-arzenálra és hadászati képességekre vonatkozóan, illetve a hírszerzési háttér bemutatása a hidegháború nagy konfliktusai esetében (pl. Koch, 1993; Scott, 2015).

A beszervezésre és hálózatépítésre koncentráló írások eddig nem fordítottak túl sok gondot a szervek által termelt iratanyagra, az így kitermelt diskurzusokra, ami tanulmányom fókuszában áll, ennyiben más a nézőpontom a megidézett nyugati szerzőkhöz képest. A hazai oktatástörténeti szakirodalomban még nem foglalkoztak a témával, amit magyarázhat, hogy az elhárítás, kémkedés problémaköre hagyományosan a politikatörténethez tartozik (az ÁBTL munkatársai révén itt már nagyon sok, színvonalas munka áll rendelkezésre), és kevéssé hozzáférhető iratanyaggal rendelkezik. Első lépésként a forráscsoport bemutatását és lehetséges tipológiáját tûztem ki célul, a korpusz leszúkítése

\footnotetext{
${ }^{1}$ CIA-RDP78-03921A000200230001-0. Office of Training Bulletin, 1957. december 1. Valamennyi fordítás a sajátom.

${ }^{2}$ CIA-RDP60-00594A000300030030-8. Office Memorandum. 1958. április 9.
} 
után vált lehetővé az ügynökségi jelentésekben rejlő lehetőségek kibontása és a dokumentumok elsődleges elemzése, illetve további kutatási irányok felvázolása.

\section{A FORRÁsCSOPORT BEMUTATÁSA}

Az amerikai Hírszerző Ügynökség elektronikus olvasószobájában (CIA Electronic Reading Room, https:/ / www.cia.gov/library/readingroom/home) folyamatosan frissülő, 25 évnél régebbi információkat tartalmazó adatbázisban kereshet az érdeklődő olvasó, 2017 eleje óta. A publikus kereshetőség törvényi előfeltétele a Freedom of Information Act (FOIA) általános hatálya - az 1966-ban született törvény biztosítja a hozzáférhetőséget, amit korlátozhat az egyéni érdek, személyes, vagy érzékeny adatok jelenléte (Privacy Act, 1974), illetve a titkosított, majd feloldott adatok kezelésével kapcsolatos végrehajtási rendelkezések (Executive Order 13526, 2009). Mindezen megszorítások mellett is nagyon sok információhoz juthatunk az oldalon, ami rendkívüli tartalékokkal szolgálhat a történeti kutatás számára.

A kifejezésként elindított keresésre („Hungarian education”) mindössze 7 találatot kaptam, az egymástól független kétszavas keresésre (Hungary education) már 1226-ot (2017. 02. 25-i adatok). A megadott időhatárokat a CIA megalapítása, 1947 és 1960 (a hosszú ötvenes évek) jelentette, a kommunista hatalomátvételnek, a rendszer megszilárdulásának, összeroppanásának, majd újbóli restaurációjának egymást követő szakaszaival. Az 1226 találat nagy többsége természetesen nem a magyar oktatással foglalkozik, csak előfordul(nak) benne a keresőkifejezés(ek), ezért szükséges volt a kapott találatok megtisztítása. Mivel a magyar iskolára koncentráltam, kiszúrtem az érintkező témákat is, melyek későbbi kutatások tárgyai lesznek:

- a felsőoktatás világát,

- a speciális, inkább a felsőoktatáshoz közelebb eső intézménytípusokat (például a katonai, tiszthelyettesi iskolákat, a Vörös Akadémiát),

- a tudományos-akadémiai szférát,

- az ifjúsági, ismeretterjesztő, kulturális-társadalmi és egyéb tömegszervezetek jelenségét (pl. KISZ, DIVSZ, VIT),

- a szovjet-magyar cserekapcsolatokat,

- továbbá a statisztikai adattájékoztatást.

29 dokumentum maradt meg a szúrés után, melyek a magyar iskoláról, iskolarendszerről, egyes speciális iskolatípusokról (főleg a szakképzés esetében) és az oktatás - nevelés változó környezetéről szólnak - összehasonlításként: a hazai felsőoktatásról 24 iratot találtam ugyanerre az időszakra vonatkozóan. Több szempont alapján lehet a 29 elemből álló csoportot tipizálni, és karakterisztikát felállítani. 16 önálló jelentés született, melyek egyetlen témája a magyar oktatás, a fennmaradó 13-ban pedig egy-egy hírlevél részeként, vagy a szatellitállamokat bemutató összehasonlításban jelent meg a magyar iskoláztatás (ez 
utóbbi esetben csak abban az esetben válogattam be az adott szövegrészletet, ha egy-két mondatnál hosszabban foglalkozott az összefoglaló a hazai oktatással). A dokumentumtípusok szintén megkülönböztető szerepet töltenek be: a napi, heti és havi jelentések, sajtó- és rádiószemlék, összefoglalók és belső memók csak néhány példa a változatos kínálatból.

A következő differenciáló szempontot az információk forrása jelentette. Ez általában Magyarországon megjelent újságcikkek angol nyelvú fordítását, rádióadások lehallgatását jelentette, esetleg külföldön megjelent írások felhasználásával készültek a jelentések - többek között hírügynökségek, emigráns szervezetek, az USA-kormányzat által fenntartott intézmények szolgáltattak ilyenkor alapanyagot. Az állami-, vagy pártszervek által kiadott hivatalos jelentések, adatok szintén gyakran szerepelnek, néha disszidensek beszámolóival is találkozhatunk (erre általában csak következtetni lehet, mint például egy magyar orvostanhallgató átlagos napjának leírásánál, ahol több, E/1. személyú idézet is található). ${ }^{3}$ A publikált cikkeken kívül általában nem tüntették fel a készítők a forrást: ki van törölve az azonosítást lehetővé tevő rubrika, vagy ismeretlen eredetúként van feltüntetve az információtartalom, az anonimizálásnak természetesen több oka is lehetett. Külön csoportot képeznek a becslések (estimates), várható fejlemények megjóslása (possible developments), trendek összefoglalása (summaries of trends), melyek mindig a már meglévő adatok felhasználását és összefoglalását jelentették. Ilyenkor általában a társszervektől is gyứjtöttek be információkat, amiket az irat elején például így jeleztek: "This report is a result of a joint collection effort by the Air Force, the Navy, the Army, and CIA..." 4 Az elsô képen egy jellemző irat-fejlécet mutatok be (a tárgyalás során még szóba kerül majd a dokumentum), a kitakart részletekkel együtt.

Az ország megjelölése alatt a tárgy található, a magyar oktatásról szólók a tágabb, szociológiai jelzet alatt találhatók, néha a vallás mellett. A legtöbb irat publikációkból származik, tehát itt a forrás a lapokat jelenti (máskor rádióadásokat). A dátum szerinti besorolásnál mindig a hírszerzésen belüli megosztás (Date Distribution) évszámát vettem alapul, jóllehet gyakran más évből származik az eredeti forrás (Date of Information), de a CIA katalogizálásánál is az előbbit vették figyelembe, így ezt a gyakorlatot követtem. A vastagon bekeretezett szöveg az USA nemzetbiztonsági érdekeire való hivatkozást tartalmaz, illetve felhívja a figyelmet az Espionae Act (Kémkedési törvény, 1917) hatályára, ami tiltja az információk illetéktelen kezekbe juttatását. A dokumentum legtetején a minősítés alóli feloldás dátuma található, illetve, hogy ez a verzió meg van tisztítva az érzékeny adatoktól (Sanitized Copy).

\footnotetext{
${ }^{3}$ CIA RPD80-0089A00060050334-6. The Daily Program of a Hungarian Medical Student. 1954. március 19.

4 „Ez a jelentés a Légierő, a Tengerészet, a Hadsereg és a CIA közös erőfeszítésének eredménye..." CIA RPD80T00246A000700320001-8. Munitions Storage Site. 1957. április 15.

${ }^{5}$ Forrás: RDP80-00809A000700060285-8. Educational Gains and Problems in Hungary. 1952. május 3.
} 
1. ábra. CIA-irat fejléce ${ }^{5}$

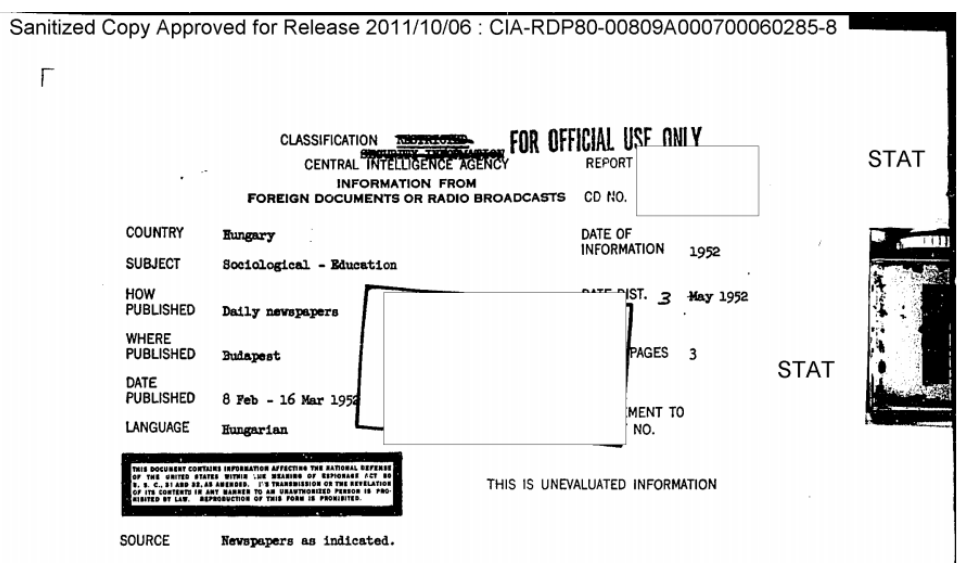

Természetesen ilyen kis elemszámnál nem vonható le nagyobb következtetés az évenkénti változásokból (1. táblázat), két dolog mindenesetre megállapítható. Az egyik, hogy a korszak elején (1947-ben) és végén (1959-ben) nem keletkezett dokumentum (vagy nem hozták még ezeket nyilvánosságra), továbbá, hogy 1956 után nem ugrott meg az oktatási témájú jelentések száma, ellentétben például a gazdasági-politikai riportokkal, melyek első látásra is növekvő tendenciát mutatnak (az 1952-es év kiemelkedő adata nem magyarázható a rendelkezésre álló információk alapján).

\begin{tabular}{|l|l|}
\hline Évszám & Dokumentumok száma \\
\hline 1947 & 0 \\
\hline 1948 & 1 \\
\hline 1949 & 1 \\
\hline 1950 & 3 \\
\hline 1951 & 6 \\
\hline 1952 & 5 \\
\hline 1953 & 2 \\
\hline 1954 & 1 \\
\hline 1955 & 3 \\
\hline 1956 & 2 \\
\hline 1957 & 3 \\
\hline 1958 & 2 \\
\hline 1959 & 0 \\
\hline
\end{tabular}

1. táblázat. A CIA magyar oktatási tárgyú iratai, évenkénti bontásban

A szövegek tematikai fókusza adja az utolsó nézőpontot, ami alapján csopor- 
tokra lehet osztani és elemezni az iratokat:

- a szatellit-államok összehasonlító kontextusa,

- a hazai oktatási rendszerról és módszerekről szóló általános leírások,

- a szakképzés kérdései,

- politikai változások és az iskolarendszer átalakulása,

- 1956 hatása.

A felvázolt tipológia a forrásokhoz alkalmazkodik, ami egyben a múfaji kínálatot is lefedi, hiszen az általános, tendenciákat felvázoló, komparatív dokumentumok éppúgy megtalálhatók benne, mint az egyedi eseményekről és intézményekről szóló tudósítások. A kutatás jelenlegi állapotában nem tudjuk, hogy milyen mértékben használták fel az így összegyứjtött ismeretanyagot a különböző döntéshozói szintek, jelen esetben csak az a fontos, hogy milyen képzetek álltak rendelkezésre a magyar oktatási rendszerről (a hírszerzés révén) az amerikai vezetésnek.

\section{A MAGYAR OKTATÁS A BÉKETÁBORBAN}

Négy összehasonlító beszámolót találtam (1951-ből, 1954-ből, 1955-ből és 1957ből), melyeket összeköt, hogy a rendszer sebezhető pontjait, a problémákat próbálták kimutatni a rendelkezésre álló cikkekből, rádióadásokból és a politikai megnyilatkozásokból. Az első irat már a címében is utal az előbb említett nézőpontra (Domestic Vulnerabilities, körülbelül: belföldi sebezhető/gyenge pontok), ${ }^{6}$ listát készítve Lengyelország, Csehszlovákia és Magyarország támadási felületeiről. 1951. augusztus 21. és szeptember 16. közti rádióadások lehallgatásából áll össze az anyag, ami az évnyitók ünnepi hangulatán és a növekvő beiskolázási adatokon kívül rögzítette a tanári presztízs és a tanórai fegyelem múlt évi csökkenését, a tanárképzés színvonalemelésének igényét mindezt Darvas József közoktatásügyi miniszter beszámolójából idézik. Egy szerkesztőségi jegyzet a szülőket figyelmeztette a tankötelezettség teljesítésére, egy másik adás az alap- és középfokú matematika-oktatás hiányosságait kárhoztatta, mint ami idegen a marxista ideológiától, hiszen nem teljesíti a szocialista építés igényeit. A jelentés írói feltételezik a régi értelmiséggel való leszámolás végigvitelét, hiszen a tanárok többsége is még a Horthy rezsim „lélektelen magoló gyakorlatát” (,soulless cramming”) ismeri - számtalan egyéb példát sorolnak még más gazdasági területekről a régi rendszer maradványaira.

A következő összeállítás valamivel több, mint három hónapos sajtófigyelésen alapult (1953 októbere és 1954. január 10. között), külföldi hírügynökségek rövid beszámolóit vették alapul Albánia, Magyarország, Lengyelország és Csehszlovákia vonatkozásában. ${ }^{7}$ A téma a vallás és oktatás kérdésköre volt, de az első szempont csak a lengyeleknél bukkant fel, a magyarok esetében egy svéd

${ }^{6}$ CIA-RPD78-0486A000200050009-5. Indications of Domestic Vulnerabilities. 1951. október 24.

7 CIA-RPD80-0809A000700170375-6. Information on Religion, Education and Public Information in the Satellites. 1954. április 22. 
lapra hivatkoznak, ami a bécsi Reuters tudósítóját idézi, egy Köznevelés cikkel kapcsolatban (többszörös tehát az áttétel). Újra a tanári hiányosságok merülnek fel (a cikk címe is ez), az alacsony színvonalra példa, hogy gyakran a diákok javítják ki pedagógusaik helyesírását, kiejtését; a matematika-tanárok pedig még a négy alapmúvelettel és a tizedes átváltásokkal kapcsolatban is bizonytalanok. A magyar illetékesek következtetése szerint ez a politikai képzés hiányából is fakad, a tanárok nem olvasnak eleget és nincs politikai érdeklődésük.

Az orosz nyelvórák számával kapcsolatos jelentés Jugoszlávián kívül valamennyi csatlósállamot áttekintette, 1950 és 1954 közötti, szelektív sajtószemlézés eredményeként. ${ }^{8}$ A Szabad Nép adatait összehasonlították a rádióadásokkal, és kiegészítették a Köznevelés cikkeivel, megállapítva a bukások magas számát, a tanár- és teremhiányt, a tankönyvek és a képzés problémáit.

Egy 1957-ből származó, 32 oldalas dokumentum sokkal nagyobb célt tûzött ki a törvényi változások áttekintésével, a Szovjetunióból kiindulva, az egész keleteurópai blokkon belül. ${ }^{9}$ Az évszámból is adódóan az ifjúság ellenállásáról, a véleményszabadság követeléséről sok szó esik, ami a pártvezetés szempontjából is felértékelte az oktatást. A Népszabadságból és a Népakaratból vett cikkeket idézve az ifjúság „,a reakció szócsöve” (,mouthpiece of a reactionary attempt”) a jelen helyzetben, akiknek inkább a munka felvételével kellene foglalkozniuk. A politikai nevelés múltbéli hiányosságainak köszönhető többek között, hogy a partizánharc dicső́tésével a diákok megtanulták, hogyan kell Molotov-koktélt készíteni és a tankok ellen bevetni.

\section{A KOMMUNISTA OKTATÁSI RENDSZER LEÍRÁSA ÉS ÉRTÉKELÉSE}

Az előző példákból szinte teljesen hiányzott az értékelés mozzanata (egyedül egy feltevés utal az író, vagy írók szubjektivitására), az adásokból, cikkekből kinyerhető információk megszûrt leírása volt a jellemző, ami a negatív jellemzőkre, hiányosságokra koncentrált, megfelelve az idegen, ellenséges hatalom hírszerzési elvárásainak. A most következő források viszont az interpretáció szándékával íródtak, itt is a nevelés - oktatás lehetséges nehézségeire helyezve a hangsúlyt. A rendszer egészét leíró szövegek sorát egy különleges példával kezdem, ami az óvodától az egyetemi szintig próbálja felvázolni a kommunista nevelés módszereit, személyes, szinte életrajz-szerú elemekkel, feltételezhetően több információforrásból származó részletekkel. ${ }^{10}$

Nem tudjuk, hogy kik, milyen körülmények között szolgáltattak adatokat (a részletek anonimizáltak), de az 1955-ben kibocsátott irat szövegkörnyezetéből

\footnotetext{
${ }^{8}$ CIA-RDP80-00809A000700230125-6. Data on Russian-Language Courses in the Satellites. 1955. június 6.

${ }^{9}$ CIA-RPDT80T00246001600780001-8. Legal Developments in Eastern Europen Countries. 1957. július 17.

10 CIA-RDP82-00046R000500310009-3. Communist Educational Methods from Kindergarten to the University Level. 1955. szeptember 28.
} 
kiderül, hogy egy negyedikes tanító és egy egyetemi oktató biztos, hogy volt közöttük. Az állami-ideológiai kontroll állandó jelenléte mutatkozik meg az ifjúsági szervezetekben, tankönyvekben, tananyagban és a különböző kampányokban - mindezekkel szemben a kettős nevelés jól ismert koncepcióját helyezi szembe az ismeretlen közlő. Például az Amerika-ellenes, antiimperialista szólamokra ezt válaszolja egy szülő a gyerekének: „....ne higgy el mindent, amit az iskolában tanulsz és ne emlitsd azt, amit otthon hallasz." Az egyházi iskolák visszaszorítása mellett az indoktrináció hatásait is elismeri a forrás, példaként az úttörőavatás diákok számára vonzó jellegét emeli ki, a pajtás-órák intézményét, ahol az idősebb úttörők gyakran vallásellenes oktatást folytatnak. Ezeket a hatásokat a szülők nem tudják ellensúlyozni - szól a végkövetkeztetés.

Az 1952-es összefoglalásnak két verziója létezik, melyek egymást kiegészítve adnak teljes képet a magyar oktatási rendszerról. ${ }^{11}$ A szovjet ideológiai kontroll, Rákosi és Sztálin hatéves gyerekek által történő dicső́tése itt is ki van emelve (a munkára nevelés marxista koncepciójával együtt), ugyanakkor a riport elismeri az írástudatlanság felszámolásáért vívott harc és a védőnői szolgálat eredményeit. A túlzsúfoltság, szegényes környezet és tanárhiány miatt a szülők nem mernek tiltakozni, hiszen ezt a hatalom később ellenük fordíthatja. A tanárok rossz helyzete részletesen ki van elemezve: 40 fős osztályok, másodállások, gyakori áthelyezések, a tanár hibáztatása a bukásokért, a fegyelem lazulása (tanárok bántalmazása) csak néhány az említett gondok közül. A középfokú oktatásba vezető szelekciós mechanizmust részletesen feltárja a szöveg, ami a vizsga- és iskolai eredmények, a családi háttér és az úttörőszervezetben, illetve DISZ-ben elért eredmények sokszoros szúrőjét jelenti.

Az utolsó csoportba tartozó jelentés szintén szemtanú közlésén alapulhat (feltételezhetően egy Múegyetemen dolgozó mérnökről van itt szó), ami hitelesebbé teszi a forrást, szemben az 1952-es, kompilációnak tưnő verzióval. ${ }^{12} \mathrm{Az}$ iskolatípusokat és a továbbhaladás logikáját, illetve ennek mesterséges leszúkítését tárgyilagosan írja le a szerző, valószínúleg a saját nézoópontjából emeli ki a technikumi diákok előnyben részesítését a gimnazistákkal szemben. A társadalmi kategóriák meghatározó százalékos arányainak ismertetése után a még mindig magas színvonalú képzést nyújtó Kandó Kálmán Mérnöki Technikumról részletesebben szól az író (feltehetőleg a Híradás- és Múszeripari Technikumról van szó), ami a diákok számára a kiemelkedés lehetőségét nyújtja, hiszen „a kommunista Magyarországon (... a mérnökök magas pozíciót és jövedelmi szintet élveznek." A továbbiakban a felsőoktatásról van szó, ennek ismertetésétől azonban itt is (ahogyan az előző dokumentumnál) eltekintek.

11 CIA-RPD80-00809A000600020196-9. Educational System. 1952. július 17. CIA-RPD8200047R000100480001-6. Educational System. 1952. július 17.

12 CIA-RDP80T00246A004000470001-5. Educational System. 1958. július 7. 


\section{A SZAKKÉPZÉS KÉRDÉSEI}

A tervgazdaság és gyorsított iparosítás (gazdaság)politikai környezetében különösen fontos volt a szakképzés területe, illetve a különböző képzési formák kibocsátó létszámainak és a népgazdasági ágazatok igényeinek összehangolása, ami mindig újabb és újabb korrekciókat eredményezett a rendszeren belül.

Az építőiparba kerülő szakmunkások számát például 1950-ról 1951-re vonatkozóan 60 százalékkal tervezték növelni, a mérnökképzés volumenét is bővíteni kellett, hogy teljesítsék az ötéves terv számait ${ }^{13}$ - a Friss Újság, amiből a cikket ismertették, már nem sokáig létezett egyébként (Horváth, 2013. 25. o.). A szakképzés további számait, az új iskolatípusokat (például a dolgozók iskoláit) bemutató írást ${ }^{14}$ egy magyar politikát népszerûsítő, olasz nyelvú követségi periodikából vették át (Bollettino Ungherese, 1. Csorba, 2010. 142. o.; 149. o.), egy év múlva különböző újságcikkek alapján ugyanerről az extenzív fejlesztésről adtak hírt, ${ }^{15}$ illetve a tervszámok pótlólagos felemeléséről - ösztöndíjakkal és diákjóléti juttatásokkal próbált a kormány még több diákot a szakképzésbe csábítani. ${ }^{16}$

Egyetlen teljes Köznevelés-cikket találtam a források között, ${ }^{17}$ ez pedig Evellei István írása a közgazdasági középiskolák első negyedéveinek eredményeiről (Evellei, 1951). Ha összevetjük az eredeti magyar szöveget és az angol változatot a CIA-archívumban, jelentős eltérést tapasztalhatunk. Kimaradt az ideológiai háttér, az 1950. márciusi párthatározatra való utalás és csak az adatok, következtetések maradtak meg, jóllehet nem szerepel a dokumentumtípus meghatározásában, hogy kivonat (Digest) lenne. A különbség arra hívja fel a figyelmet, hogy a többi újságcikk esetében is előfordulhatott szelekció vagy rövidítés (bár a többi esetben nem végeztem el ilyen vizsgálatot). Visszatérve az ismertetett íráshoz: a fő motívum az alacsony tanulmányi színvonal (sok közepes és elégséges osztályzat) volt, amit megint csak az iskolai fegyelem hiányosságainak (közvetve a tanárok hibájának) tudott be a pártvezetés. A színvonalesés magyarázata mindig hasonló maradt, az ideológiai dominancia miatt fel se merülhetett a valódi okok elemzése, például, hogy a munkás - paraszt származású gyerekeknek lehet, hogy tényleg nehéznek bizonyult a tananyag elsajátítása - Sáska Géza (2006) már részletesebben ismertette ezt a jelenséget.

A Munkaerőtartalékok Hivatala (MTH) 1950-től múködtette az iparitanulóképzést (Gyekiczky, 1985), amiről egy részletesebb, valószínúleg nem a sajtóból

13 CIA-RPD80-00809A000600350602-4. Intensify Training of Construction Workers; Convict Hungarian Professors. 1950. október 24.

14 CIA-RPD80-00809A000600340694-1. Schools Step Up Worker Training. 1950. szeptember 20.

15 CIA-RPD80-00809A000700030243-7. School Enrollment Reaches New High; Regulate Sport Clubs. 1951. december 1.

16 CIA-RDP80-00809A000600400050-1. More Students to Get Vocational Training; Miners Get New Housing. 1951. június 21.

17 CIA-RDP80-00809A000600400186-1. First-Quartier 1950-51 Results in Hungary's Economic High Schools. 1951. július 3. 
származó információs anyag található 1955-ből. ${ }^{18}$ Az azonosítást lehetővé tévő adatok teljesen ki vannak takarva, a szokásosnál is nagyobb az irat anonimizáltsága. Az adatok felsorolása és a politikai képzés fontosságának kihangsúlyozása után jön az érdemi mondanivaló a képzésben felmerülő problémákról. A tanárok többsége valójában munkás és nincs végzettsége, csak a munkaruháján látható jelzés különbözteti meg a diákoktól, az iparimunkás-tanulók bandákban járkálnak az utcán, hangosak, durvák és trágár a beszédük, az uniformisuk miatt „Fekete Hollóknak” nevezik őket. ${ }^{19}$ Egy-két megjegyzés valószínúsíti, hogy a Demokratikus Ifjúsági Világszövetség kínai delegációjától származnak az információk, akik Diósgyőrbe és az Illatos úti Rákosi Mátyás Központba is ellátogattak. Az előbbiről jó benyomásokat szereztek a vendégek, a budapesti létesítménynél a rossz higiéniára és az étkezés hiányosságaira panaszkodtak a tanulók, az egyikük ezt mondta a delegáció egy tagjának: "Jó hogy itt vagytok, mert igy legalább ma este több és jobb ételt kapunk." Nem ismert a forrás eredeti évszáma, lehetséges, hogy még az 1949-es Világifjúsági Találkozó idején keletkezett, amikor a magyar fóvárosban volt a rendezvény.

\section{VÁLTOZÁSOK ÉS ÁTALAKULÁS}

A szovjetizálás folyamatát rögzítő tudósítások tömörek, szúkszavúak, csak a tényeket tartalmazzák, a források még kevésbé ismertek és nem következtethetők ki, ellentétben a korábbi esetekkel. A magyar oktatásról szóló legelső hír 1948 végéből származik, ebből megtudjuk, hogy Ortutay miniszter elvégezve a feladatát (,,a katolikus ellenállás megtörését és Mindszenty likvidálását”) Kállainak adja át a helyét, aki befejezi az oktatási rendszer kommunista átalakítását. ${ }^{20}$ Újra csak a vallásos oktatás kérdése merült fel 1949-ben: egy zürichi lapban (az Israelitisches Wochenblatt-ban) a magyarországi zsidó közösség, a Rabbiszövetség és a Zsidó Világkongresszus Magyar Szekciójának közös állásfoglalása jelent meg az amerikai riportok cáfolataként. ${ }^{21}$ A zsidó iskolák továbbra is szabadon múködnek, a kommunisták nem üldözik a vallásokat és a félretájékoztatás csak árt a kelet-európai zsidóknak - szólt a jelentés, ami lehetséges, hogy egy alku eredményeként jelenhetett meg külföldön.

A fordulat évei után (1948-1949) megszaporodtak a jelentések: egy „B” jelzésú, korlátozott hozzáférésú irat ( $\mathrm{a}$ „, $\mathrm{B}$ ” az amerikai adminisztráció számára jelezte az információk kevésbé fontos jellegét, szemben az „ $\mathrm{A}^{\prime \prime}$ minősítéssel)

18 CIA-RPD82-00046R000500340002-7. Training Centers for Industrial Apprentices. 1955. szeptember 21.

19 Érdekes párhuzam, hogy egy 1961-es állambiztonsági fellépés előtt ugyanilyen néven figyeltek meg és gyưjtöttek az adatokat katolikus bázisközösségekről, illegális hitoktatókról (legújabban 1. Wirthné, 2015).

20 CIA-RDP82-00457R002200280002-9. Hungarian Communist Plans Regarding Catholic Opposition and Education System. 1948. december 29.

21 CIA-RDP80-00809A000600240909-6. Zionists Jailed for Emigration Activities: Rabbis Deny Religious Persecution. 1949. augusztus 10. 
már 1950-ben felvázolta az eddigi fejlődést. ${ }^{22}$ Az előzó évben felmerülő nehézségek továbbra is érvényesek voltak: hiányoztak az ideológiailag megfelelően képzett szakos tanárok, a bukások és lemorzsolódás aránya nagyon magas volt, kevés munkás - paraszt származású diák akart továbbtanulni. A bukásokat (főleg a paraszti származású gyerekek esetében) az ellenség aknamunkájának eredményeként határozta meg a pártvezetés, az ellenség körébe az egyházat helyezve. Az előállt helyzetért a Minisztérium szabotáló munkája volt felelős, ami akadályozta a munkás - paraszt arány növelését, és előnyben részesítette az elmúlt rendszer uralkodó osztályait a tankönyvi anyag szoros számonkérésével. Mindez az 1950 márciusában kelt KV-határozatra utal (ennek elemzéséhez: Knausz, 1994. 46-60. o.; Kardos, 2003), anélkül, hogy megnevezné az újabb fordulat írásos jelét az MDP részéről.

Számos probléma nehezítette a korábban már említett gazdasági tervek megvalósulását. Az egyik az általános iskolások lemorzsolódása volt a Népszava szerint (itt kivételesen ott az író, Máté Vera neve): a szülők kivették őket, hogy dolgozzanak, sorba álljanak; a túlterhelés, iskolán kívüli tevékenységek kötelezővé tétele szintén súlyosbította a helyzetet, így a helyi tanácsok harcot indítottak a gyerekek iskolában való bent tartásáért. ${ }^{23} \mathrm{Az}$ iskolai fegyelem lazulása (késések, hiányzások, nem megfelelő felkészültség) volt a másik nagy problémaforrás, amit a fegyelmi intézkedések nagy aránya is jelzett - ez a beszámoló már egy 1951-es Magyar Nemzet cikkből származik, ami az igazgatókat is hibáztatta az ellenőrzések elmaradásáért. ${ }^{24}$ Ugyanezek a problémák a következő évben újra megjelentek a CIA iratanyagában, ezúttal a felsőoktatásra helyezve a hangsúlyt, ismét csak Népszava cikkeket megosztva. ${ }^{25}$

A továbbiakban már csak rövid hírek vannak az 1956-os forradalomig, többek között a politikai nevelés további erősítését bejelentő Jóború beszédről, ${ }^{26}$ a Rákosi Mátyás-tanulmányi versenyekről, ${ }^{27}$ vagy egy Ágoston György-cikk lefordításáról, ami a Természet és Társadalom 1955. decemberi számában jelent meg. ${ }^{28}$ Ez utóbbi közlemény a legérdekesebb, hiszen kommentár nélkül szerepel a CIA-adatbázisában, 1956 decemberi közzététellel. Az eredeti magyar cím egy kicsit eltér az angol változattól (Nevelés és öröklés, nevelés és társadalmi környezet), nehezen lehet megmagyarázni, hogy az adott történelmi kontextusban milyen információtartalmat hordozhatott az írás a hírszerzés számára,

\footnotetext{
22 CIA-RPD79-01090A000300050001-3. Summaries of Trends and Developments. 1950. december 5.

23 CIA-RPD80-00809A000600370942-5. Deplore State of Education. 1951. február 15.

24 CIA-RPD80-00809A000600380661-6. Criticize Discipline in Hungarian Schools; Set Up Education Council. 1951. április 2.

25 CIA-RPD80-00809000700060285-8. Educational Gains and Problems in Hungary. 1952. május 3.

${ }^{26}$ CIA-RDP79T01146A001200180001-0. Further Sovietization of Hungarian Education reported. 1952. szeptember 3 .

27 CIA-RPD80-00809A000700120272-5. Competitive Examinations for Students of Hungarian Intermediary Schools. 1953. július 23.

${ }^{28}$ CIA-RPD80-00809A000600120021-5. Education and Heredity, Education and Social Environment in Hungary. 1956. december 4.
} 
lehetséges magyarázatul szolgálhat, hogy a marxista neveléstudomány illusztrációjaként iktatták a szöveget, a feltorlódott események miatt késett ilyen sokáig a feldolgozás.

\section{HATÁsA}

A forradalom kitörésének politikai-társadalmi okairól, a restauráció és konszolidáció körülményeiről számos elemzés született, itt most csak az időhatárokon belül keletkezett, az oktatásról szóló szövegekkel foglalkozom. A Múvelődésügyi Minisztérium nyílt jelentése az 1956-1957-es tanév tapasztalatairól szól, amit a CIA is átvett ${ }^{29}$ - az ellenforradalmi körülmények utáni rekonstrukció elemzése nem tér ki az okok keresésére, csak a megszokott statisztikai összefoglalót kapjuk, elfedve a valódi problémákat.

Egy 1957. áprilisi heti összefoglaló sokkal negatívabb képet fest a helyzetről ${ }^{30}$ - ezek az összefoglalók belső használatra készültek, a források megjelölése nélkül foglalták össze az adott hét legfontosabb külpolitikai eseményeit. Az iskolák egységes ellenállásáról, a diákok és tanáraik egységes fellépéséről szerzünk itt tudomást, különösen a nyelv- és hitoktatás terén kiélezve a harcot. Jóború Magda beszédeit idézve próbálja a jelentés írója kitalálni a hatalom reakcióit, amik eléggé vegyesek: vannak hívei még az ifjúság megnyerésének, de a kemény megtorlásnak is, az 1956 előtti állapotok visszatérése fenyeget. Egy budapesti tanár Magyar Ifjúságban megjelent beszámolója a „kicsi Péter” gyermekek általi megszégyenítéséről és megveréséről szól, aki egyedül nem volt hajlandó részt venni az osztályából a hitoktatáson. A példa a reakció és az ellenforradalom veszélyével riogatta a közvéleményt és gyakori volt a korban (Somogyvári, 2016), ez többek között az állambiztonság és a rendőrség embereinek megjelenését is eredményezte az iskolákban, 12 éves gyerekek személyes iratai között kutatva.

1957 nyarán összegezték a Hivatalon belül a lehetséges ellenállási potenciált, melyek között az ifjúság is helyet kapott. ${ }^{31}$ Ha figyelmesebben átolvassuk az események leírását, csak olyan információkat találunk, ami bármilyen amerikai döntéshozó, vagy érdeklődő olvasó előtt ismert lehetett, hiszen a New York Times-ból, az ENSZ-től, illetve a Szabad Európa Bizottságtól származtak a fejezet információi, amit csak szintetizáltak a készítők. Az 1956-os ifjúsági szervezetekből sokan disszidáltak Nyugatra, feltehetően egy ilyen szemtanúi beszámoló is fennmaradt 1958-ból, ami a felsőoktatás tekintetében releváns, tehát itt most nem elemzem. ${ }^{32}$

29 CIA-RDP80T00246A002300340001-8. Report of the Ministry of Education of the Hungarian People's Republic on Educational Progress in the School Year 1956-1957. 1957. július 1.

${ }^{30}$ CIA-RDP79-00927A0012000300001-7. Current Intelligence Weekly. 1957. április 4.

31 CIA-RPD81-01043R002600010004-4. Resistance Factors and Special Forces Areas Hungary. 1957. augusztus 1 .

32 CIA-RPD80T00246A040100260001-7. Information Report. 1957. február 8. 


\section{BEFEJEZÉS}

A magyar oktatástörténet számára érdekes adalékokkal szolgálhat a tanulmány, illetve a további kutatások, melyek közül különösen érdekesek lehetnek a felsőoktatásról, a tudományos-akadémiai szféráról, vagy az ifjúsági szervezetekről szóló részek. Nem ismerjük a jelentések íróit, felhasználóit, a feldolgozás folyamatát, így szükségszerúen a szövegekre kell koncentrálni a vizsgálat során, ami sajátos nézőpontot jelent az ötvenes évek (és a későbbi évtizedek) szocialista neveléséről és oktatásáról.

A keleti blokkon belül Magyarország és az oktatás ügye nem volt hangsúlyos, ezen az 1956-os forradalom változtatott, ami teljes meglepetést okozott az amerikai hírszerzésnek. A dokumentumok egyik fó intenciója a szovjet típusú rendszerek gyenge pontjainak feltérképezése volt, aminek részeként a magyar fiatalságban 1956 után már potenciális lehetőséget láttak a nyugati ügynökségek, például az emigráns hallgatók beszervezésével. Az iratok értelmezéséhez a külső adatok (forrás- és múfaj-megjelölések, a fejlécen közölt adatok) megfelelő értelmezése nagy segítséget nyújt, itt azonban mindig számításba kell venni a titkosítás alóli feloldás nemzetbiztonsági, gazdasági, személyiségi jogi korlátait. Az online kereséssel kitapinthatóvá váltak azok a tematikai fókuszok, amelyek alapján felvázolható a CIA-jelentések egy lehetséges tipológiája - ezt a logikát követte a tanulmány is, a távolabbi nézőponttól haladva az egyre inkább részletekbe menő vizsgálatokig.

Az első két fejezet jellemző irattípusokat ismertet: a béketáboron belüli összehasonlító vizsgálatok jellemző forráscsoportot jelentenek; csakúgy, mint az egy-egy ország általános jellemzéséhez hozzátartozó, időnként önálló iratként is előforduló, oktatási rendszereket bemutató riportok. A magyar oktatás kérdései közül leginkább a szakképzés foglalkoztatta a jelentések íróit, ami a gazdasági teljesítőképesség dimenziójához tartozott, a politika mellett ugyanis a gazdaság jelenthette a másik fő szempontot az információszerzéskor. Ennek megfelelően minden személyi-politikai változást rögzítettek, illetve a hosszabb távú tendenciákhoz (pl. államosítás, hitoktatás kérdése) igyekeztek adatokat gyújteni az ismeretlen ügynökök. 1956 hosszú távú hatása, az ellenállás lehetőségeinek feltérképezése jelenti az utolsó fontos szempontot témámban, a CIA irattermelésének magyar oktatásra vonatkozó dokumentumait illetően.

A későbbi kutatásokra számos fontos kérdés tisztázása vár, többek között a CIA, az amerikai bel- és külpolitika kapcsolata, a Magyar Népköztársaság diplomáciai tevékenysége 1956 után, az egyházi körök befolyása (Mindszenty esetében), a Szovjetunióról és más szatellit-országokról szóló jelentések összevetése, az ideológiai kérdések elemzése - a sort még tovább folytathatnánk. A további vizsgálatoknak meg kell teremteniük a megfelelő módszertant, feltenni a releváns kutatási kérdéseket, hiszen az oktatástörténetben még kevéssé kutatott területről van szó, írásom ebbe kívánt rövid betekintést nyújtani. 


\section{KÖSZÖNETNYILVÁNÍTÁS}

Az írás az Emberi Erőforrások Minisztériuma ÚNKP-17-4 kódszámú Új Nemzeti Kiválóság Programjának támogatásával készült.

\section{LEVÉLTÁRI FORRÁSOK}

Central Intelligence Agency (CIA) Information Report. RDP82-00457R002200 280002-9. Hungarian Communist Plans Regarding Catholic Opposition and Education System. 1948. december 29.

CIA Information from Foreign Documents or Radio Broadcasts. RDP8000809A000600240909-6. Zionists Jailed for Emigration Activities: Rabbis Deny Religious Persecution. 1949. augusztus 10.

CIA Information from Foreign Documents or Radio Broadcasts. RPD8000809A000600340694-1. Schools Step Up Worker Training. 1950. szeptember 20.

CIA Information from Foreign Documents or Radio Broadcasts. RPD8000809A000600350602-4. Intensify Training of Construction Workers; Convict Hungarian Professors. 1950. október 24.

CIA-RPD79-01090A000300050001-3. Summaries of Trends and Developments. 1950. december 5 .

CIA Information from Foreign Documents or Radio Broadcasts. RPD8000809A000600370942-5. Deplore State of Education. 1951. február 15.

CIA Information from Foreign Documents or Radio Broadcasts. RPD8000809A000600380661-6. Criticize Discipline in Hungarian Schools; Set Up Education Council. 1951. április 2.

CIA Information from Foreign Documents or Radio Broadcasts. RDP8000809A000600400050-1. More Students to Get Vocational Training; Miners Get New Housing. 1951. június 21.

CIA Information from Foreign Documents or Radio Broadcasts. RDP8000809A000600400186-1. First-Quartier 1950-51 Results in Hungary's Economic High Schools. 1951. július 3.

CIA Information Report, Soviet Satellites. RPD78-0486A000200050009-5. Indications of Domestic Vulnerabilities. 1951. október 24.

CIA Information from Foreign Documents or Radio Broadcasts. RPD8000809A000700030243-7. School Enrollment Reaches New High; Regulate Sport Clubs. 1951. december 1.

CIA Information from Foreign Documents or Radio Broadcasts. RDP8000809A000700060285-8. Educational Gains and Problems in Hungary. 1952. május 3.

CIA Information Report. RPD80-00809A000600020196-9. Educational System. 1952. július 17. 
CIA Information Report. RPD82-00047R000100480001-6. Educational System. 1952. július 17.

CIA Current Intelligence Digest. RDP79T01146A001200180001-0. Further Sovietization of Hungarian Education reported. 1952. szeptember 3.

CIA Information from Foreign Documents or Radio Broadcasts. RPD8000809A000700120272-5. Competitive Examinations for Students of Hungarian Intermediary Schools. 1953. július 23.

CIA Information Report. RPD80-0089A00060050334-6. The Daily Program of a Hungarian Medical Student/Professors and Subjects studied. 1954. március 19.

CIA Information from Foreign Documents or Radio Broadcasts. RPD800809A000700170375-6. Information on Religion, Education and Public Information in the Satellites. 1954. április 22.

CIA Information from Foreign Documents or Radio Broadcasts. RDP8000809A000700230125-6. Data on Russian-Language Courses in the Satellites. 1955. június 6.

CIA Information Report. RDP82-00046R000500310009-3. Communist Educational Methods from Kindergarten to the University Level. 1955. szeptember 28.

CIA-RPD80-00809A000600120021-5. Education and Heredity, Education and Social Environment in Hungary. 1956. december 4.

CIA-RPD80T00246A040100260001-7. Information Report. 1957. február 8.

CIA Weekly Summary. RDP79-00927A0012000300001-7. Current Intelligence Weekly. 1957. április 4.

CIA Information Report. RPD80T00246A000700320001-8. Munitions Storage Site/Internal Guard Station and Training School. 1957. április 15.

CIA Unclassified Report. RDP80T00246A002300340001-8. Report of the Ministry of Education of the Hungarian People's Republic on Educational Progress in the School Year 1956-1957. 1957. július 1.

CIA Disposition of Monthly Report. RPDT80T00246001600780001-8. Legal Developments in Eastern Europen Countries. 1957. július 17.

CIA Report. RPD81-01043R002600010004-4. Resistance Factors and Special Forces Areas Hungary. 1957. augusztus 1.

CIA-RDP78-03921A000200230001-0. Office of Training Bulletin, No. 33. 1957. december 1.

CIA-RDP60-00594A000300030030-8. Office Memorandum. Chief/Language and Area School. Weekly Activities Report \#14. 1958. április 9.

CIA Information Report. RDP80T00246A004000470001-5. Educational System. 1958. július 7.

CIA Historical Staff (1972): The Clandestine Service Historical Series, Hungary, Volume I. May 1972. Letöltés: https://nsarchive2.gwu . edu/NSAEBB/NS AEBB206/CSHS_Hungary_Vol1.pdf, 2017 február 26. 19:54. 


\section{IRODALOM}

Békés Csaba, Byrne, Malcolm és Rainer M. János (2002): The 1956 Hungarian Revolution: A History in Documents. Central European University Press, BudapestNew York.

Borhi László (1999): Contaimnent, Rollback, Liberation or Inaction? The United States and Hungary in the 1950s. Journal of Cold War Studies, 1. 3. sz. 67-108. DOI: 10.1162/152039799316976814

Csorba László (2010): A római magyar követ jelenti. A magyar-olasz kapcsolatok története 1945-1956. Budapest. Letöltés: http://real-d.mtak.hu/538/4/dc_2 52_11_doktori_mu.pdf, 2017. február 28. 18:40.

Evellei István (1951): A közgazdasági középiskola első negyedévének mérlege. Köznevelés, 7. 2. sz. 47-48.

Gati, Charles (2006): Vesztett illúziók. Moszkva, Washington, Budapest és az 1956-os forradalom. Osiris Kiadó, Budapest.

Gyekiczky Tamás (1985): Iparitanuló-képzés az ötvenes évek Magyarországán. In: Dunay Pál és Mezey Barna (szerk.): Fiatal oktatók mühelytanulmányai. ELTE ÁJK, Budapest. 236-270.

Horváth Attila (2013): A magyar sajtó története a szovjet típusú diktatúra idején. Médiatudományi Intézet, Budapest.

Kardos József (2003): Fordulat a magyar iskolák életében: a Rákosi-időszak oktatáspolitikája. Iskolakultúra, 13. 6-7. sz. 73-80.

Knausz Imre (1994): A közoktatás Magyarországon, 1945-1956. Kandidátusi disszertáció, Budapest. Letöltés: http: //mek. oszk.hu/10000/10080/10080.pd f, 2017 február 28. 15:55.

Koch, Scott A. (1993, szerk.): Selected Estimates on the Soviet Union, 1950-1959. CIA History Staff - Center for the Study of Intelligence, Washington DC.

Kotek, Joël (1996): Students and the Cold War. Palgrave Macmillan, London. DOI: 10.1007/978-1-349-24838-4

Kotek, Joël (2005): Az ifjú gárda. A világ ifjúsága a CIA és a KGB között. Nagyvilág Kiadó, Budapest.

Paget, Karen M. (2015): Patriotic Betrayal: The Inside Story of the CIA's Secret Campaign to Enroll American Students in the Crusade Against Communism. Yale University Press, New Haven - London.

Prados, John (2006): Safe for Democracy: The Secret Wars of the CIA. Ivan R. Dee. Chicago.

Sáska Géza (2006): A társadalmi egyenlőség megteremtésének kísérlete az ötvenes évek felsőoktatásában. Educatio, 15. 3. sz. 593-608.

Scott, Len (2015): The 'Incredible Wrongness' of Nikita Khrushchev: The CIA and the Cuban Missile Crisis. History: The Journal of the Historical Association, 100. 340. sz. 210-228. DOI: $10.1111 / 1468-229 x .12104$

Sheridan, Vera (2016): Support and Surveillance: 1956 Hungarian Refugee Students in Transit to the Joyce Kilmer Reception Centre and to Higher Edu- 
cation Scholarships in the USA. History of Education, 45. 6. sz. 775-793. DOI: 10.1080/0046760x.2016.1185542

Somogyvári Lajos (2016): Iskolai hitoktatás 1957-ben. Századok, 150. 6. sz. 1535-1562.

Weiner, Tim (2007): Legacy of Ashes. The History of CIA. Doubleday. New York - London - Toronto - Sydney - Auckland.

Wirthné Diera Bernadett (2015): Katolikus hitoktatás és elitképzés a Kádárkorszakban - Az 1961-es "Fekete Hollók” fedőnevü ügy elemzése. Doktori disszertáció, ELTE BTK, Budapest. Letöltés: http://doktori.btk.elte.hu/hist/wirthne dierabernadett/diss.pdf, 2017. március 1. 12:19.

Zwerling, Philip (2011): The CIA on Campus: Essays on Academic Freedom and the National Security State. McFarland \& Company Inc. Publishers, Jefferson London. 